science@ $d$ irect.

Earth and Planetary Science Letters 222 (2004) 767-778
EPSL

www.elsevier.com/locate/epsl

\title{
A glacial warm water anomaly in the subantarctic Atlantic Ocean, near the Agulhas Retroflection ${ }^{\text {is }}$
}

\author{
Giuseppe Cortese*, Andrea Abelmann, Rainer Gersonde \\ Alfred Wegener Institute for Polar and Marine Research (AWI) Columbusstrasse, P.O. Box 120161, 27515 Bremerhaven, Germany
}

Received 26 September 2003; received in revised form 11 March 2004; accepted 19 March 2004

\begin{abstract}
ODP Site 1089 is optimally located in order to monitor the occurrence of maxima in Agulhas heat and salt spillage from the Indian to the Atlantic Ocean. Radiolarian-based paleotemperature transfer functions allowed to reconstruct the climatic history for the last $450 \mathrm{kyr}$ at this location. A warm sea surface temperature anomaly during Marine Isotope Stage (MIS) 10 was recognized and traced to other oceanic records along the surface branch of the global thermohaline (THC) circulation system, and is particularly marked at locations where a strong interaction between oceanic and atmospheric overturning cells and fronts occurs. This anomaly is absent in the Vostok ice core deuterium, and in oceanic records from the Antarctic Zone. However, it is present in the deuterium excess record from the Vostok ice core, interpreted as reflecting the temperature at the moisture source site for the snow precipitated at Vostok Station. As atmospheric models predict a subtropical Indian source for such moisture, this provides the necessary teleconnection between East Antarctica and ODP Site 1089, as the subtropical Indian is also the source area of the Agulhas Current, the main climate agent at our study location.

The presence of the MIS 10 anomaly in the $\delta^{13} \mathrm{C}$ foraminiferal records from the same core supports its connection to oceanic mechanisms, linking stronger Agulhas spillover intensity to increased productivity in the study area. We suggest, in analogy to modern oceanographic observations, this to be a consequence of a shallow nutricline, induced by eddy mixing and baroclinic tide generation, which are in turn connected to the flow geometry, and intensity, of the Agulhas Current as it flows past the Agulhas Bank.

We interpret the intensified inflow of Agulhas Current to the South Atlantic as responding to the switch between lower and higher amplitude in the insolation forcing in the Agulhas Current source area. This would result in higher SSTs in the Cape Basin during the glacial MIS 10, due to the release into the South Atlantic of the heat previously accumulating in the subtropical and equatorial Indian and Pacific Ocean. If our explanation for the MIS 10 anomaly in terms of an insolation variability switch is correct, we might expect that a future Agulhas SSST anomaly event will further delay the onset of next glacial age. In fact, the insolation forcing conditions for the Holocene (the current interglacial) are very similar to those present during MIS 11 (the interglacial preceding MIS 10), as both periods are characterized by a low insolation variability for the Agulhas Current source area. Natural climatic variability will force the Earth system in the same direction as the anthropogenic global warming trend, and will thus lead to even warmer than expected global temperatures in the near future.
\end{abstract}

(C) 2004 Elsevier B.V. All rights reserved.

Keywords: Agulhas; paleotemperature; radiolarians; South Atlantic

\footnotetext{
is Supplementary data associated with this article can be found, in the online version, at doi:10.1016/j.eps1.2004.03.029.

* Corresponding author. Tel.: +49-471-4831-1207; fax: +49-471-4831-1149.

E-mail address: gcortese@awi-bremerhaven.de (G. Cortese).
} 


\section{Introduction}

Climate is shaped by the interaction between changes in the external forcing (insolation) and several internal factors, the most important of which are atmospheric and oceanic circulation (including thermohaline, THC), and the influence on the latter of processes taking place at oceanic gateways (Fig. 1). Alterations to THC amplify the external forcing, and can cause rapid climate change, as exemplified by sudden freshwater discharges into the North Atlantic, which are known to reduce North Atlantic Deep Water (NADW) formation and meridional heat transport, cooling high northern latitudes [1]. While North Atlantic processes are surely important in affecting global climate, other regions play an additional role in amplifying climate forcings. In fact, reductions in THC could also be caused by gradual modifications of seawater properties (salinity, temperature) at sites far from the North Atlantic, but linked to it either via the ocean or the atmosphere.

Among the processes modifying the density of surface waters eventually advected to the North Atlantic (Fig. 1), we focus on the Agulhas spillage, as our core (ODP Site 1089), close to the Agulhas Retroflection area (the "Heat Gate" between the Indian and Atlantic Ocean), is optimally located to monitor the interplay between Southern Ocean and Agulhas Current (Fig. 2). Anomalous SST events in this area, and their tracing to other locations, would represent exceptional interoceanic heat-exchange events that affect the freshwater/moisture input to the North Atlantic and the resulting density of NADW source waters at the sinking locations. In fact, at these subantarctic latitudes, the Agulhas Current spillover variability into the Atlantic modulates the enormous incoming flux of salt, heat and moisture kept in store at intertropical latitudes in the Indian and Pacific Ocean, which is needed to resupply the North Atlantic and compensate for the loss of North Atlantic Deep Water (NADW) to other ocean basins.

The subantarctic area is of further importance to detect climate transfer mechanisms, as the interaction between atmospheric processes and oceanic circulation is most pronounced at the boundary between Subtropical and Subantarctic Zone (Subtropical
Front, STF), where vigorous eddy mixing is dominant both in the atmosphere (Ferrel cell) and the ocean (Agulhas Retroflection). This atmospheric/oceanic synergy (between oceanic fronts, currents, atmospheric cells and wind systems) efficiently amplifies the changes induced by the external forcing (insolation), and affects the STF position. This in turn modulates the Agulhas Current spillage in the South Atlantic, of vital importance for the THC, as water (and heat) pass from the Indian Ocean subtropical pool into the Atlantic mainly through eddies shed from this current [2].

ODP Site 1089, located at the STF, in the eddy shedding pathway of the Agulhas Retroflection, between the Southern Ocean and the Agulhas Current influence, is characterized by a continuous, high sedimentation rate $(15 \mathrm{~cm} / \mathrm{kyr})$ deposition, and therefore perfectly suited to document in detail the past surface hydrography of the Agulhas Retroflection, and its influence on the interocean heat-exchange history. While this site may not be particularly sensitive to minor/seasonal changes in Agulhas pulses, it is sensitive to major climatic shifts, which expand the influence of the Agulhas Current to our present core position (Fig. 2). Almost paradoxically, it is more suitable to trace Agulhas events than cores located in the main path of the Agulhas Current itself, where seasonal variation and continuous advection of warm water add noise to the climatic signal.

\section{Materials and methods}

\subsection{Core sampling and age model}

ODP Site 1089 is located at the South Atlantic Subtropical Front $\left(40^{\circ} 56^{\prime}\right.$ S; $9^{\circ} 54^{\prime}$ E, 4620-m water depth), and in this study, we examined the topmost $67.23 \mathrm{mcd}$ (meters composite depth), corresponding to an age of ca. $440 \mathrm{ka}$. A total of 484 core levels, at an average spacing of $14 \mathrm{~cm}$, were sampled. The average time resolution is therefore ca. 900 years, decreasing to a few hundred years close to Terminations I and II. An average of 470 radiolarian specimens was counted for each sample, and Q-mode Factor Analysis applied to the radiolarian assemblages. Details on the oceanographic data, the statistical 




Fig. 1. Station locations, thermohaline circulation, climatic mechanisms. Simplified globe with schematic atmospheric cells circulation (inset, top left). Location of the sediment and ice cores mentioned in the text, along with the path of the global thermohaline circulation upper branch (red band), and the maximum sea ice extent (light blue) for the Southern Ocean. The processes amplifying the insolation forcing, and modifying the density/buoyancy of surface waters eventually advected to the North Atlantic include (name in black, location circled in gray): changes in interoceanic salt and heat exchange, displacement of precipitation/moisture patterns by basin-scale moisture relocalization by dipoles (El Niño, North Atlantic Oscillator, Indian Dipole Mode), Indian Monsoon variability, change in Pacific and Indian Ocean water input through, respectively, the Drake Passage and the Agulhas Current (circled in orange), change in Mediterranean spillover, shelf freshwater runoff from the Arctic permafrost areas. Cyan arrows represent known (east-west Pacific via ENSO, east-west Indian via Indian Dipole Mode, northwest-southeast North Atlantic via NAO) and assumed (east Pacific to west Atlantic [32], North Atlantic- and equatorial AtlanticArabian Sea [33], Indian Ocean tropics origin for precipitation at Dome C [25]) atmospheric connections. AA=Antarctic, LIS $=$ Laurentide Ice Sheet, NADW = North Atlantic Deep Water, Med= Mediterranean. See Fig. 2 for a detail of the boxed area. 




Fig. 2. Primary production and SST distribution. Left: Annual primary production, averaged over September $1997-$ August 1998 , in $\mathrm{g} \mathrm{C}^{-2}$. Data from SeaWIFS. Frontal positions and terminology [34]: ARC $=$ Agulhas Return Current; AC = Agulhas Current; AF = Agulhas Front; STC $=$ Subtropical Convergence; STF $=$ Subtropical Front. The position of the cores discussed in the text is also shown. Note the high productivity area between the AF and the $\mathrm{STC}$ (centered around $40^{\circ} \mathrm{S}$ latitude and $20^{\circ} \mathrm{E}$ longitude), and how $\mathrm{ODP}$ Site 1089 is located on the opposite side of the Subtropical Convergence compared to cores PS2489 and PS2082. Right: Snapshot of SST data in the Agulhas region on March 3rd, 2003, from nowcast results [35] by the $1 / 16^{\circ}$ global Naval Research Lab (NRL) Layered Ocean Model (NLOM), an operational product run daily by the Naval Oceanographic Office (NAVOCEANO). This SST distribution roughly corresponds to the maximum extent of the Agulhas Current, during austral summer. (See online version of this paper for a movie showing the annual SST evolution in this area). 
properties of the reference dataset and the regression equation, as well as a detailed comparison of different proxy data from ODP Site 1089 are presented elsewhere [3].

The age model for our core was developed by correlating its $\delta^{18} \mathrm{O}$ Cibicidoides record [4] to the Vostok ice core $\delta^{18} \mathrm{O}_{\mathrm{atm}}$ curve, on a gas age scale [5]. As orbital tuning assumes that insolation variations influence environmental properties (particularly at precessional/obliquity frequencies), this chronology is an improvement over other reference timescales, since it is based on a quantity $\left(\mathrm{O}_{2} / \mathrm{N}_{2}\right)$ which is directly affected by local summer insolation, via its effect on the snow characteristic at the site of deposition. The validity of this approach is indirectly confirmed by the high correlation coefficient $(0.87)$ we obtain for the ODP Site $1089 \delta^{18} \mathrm{O}$ Cibicidoides and Vostok ice core $\delta^{18} \mathrm{O}_{\text {atm }}$ records, after application of a pass-band Gaussian filter, centered at a period of $20 \mathrm{ka}$.

\subsection{Salinity anomaly estimates}

The local salinity anomaly $\left(\delta_{\mathrm{sw}}-\delta_{\mathrm{gw}}\right)$ was calculated following a method described in detail elsewhere [6]. Only samples for which we had both a paleoSSST estimate and isotopic measurements for $\delta^{18} \mathrm{O}$ Cibicidoides and $\delta^{18} \mathrm{O} G$. bulloides were used (i.e. no interpolation was performed to derive additional values for any of these three variables). The change in surface water $\delta^{18} \mathrm{O}\left(\delta_{\mathrm{sw}}\right)$, and in global seawater $\delta^{18} \mathrm{O}$ $\left(\delta_{\mathrm{gw}}\right)$, and the resulting local salinity anomaly were derived as follows [6]:

$T^{*}=$ Radiolarian-based SSST estimate -1 (this correction accounts for the growth temperature of G. bulloides, which was used for measuring planktic foraminifera $\left.\delta^{18} \mathrm{O}\right)$

$\delta_{\mathrm{gw}}=\left(\left(\delta^{18} \mathrm{O}\right.\right.$ Cibicidoides -3.4$\left.) * 1.2\right) / 1.65$

$\delta_{\mathrm{sw}}=\delta^{18} \mathrm{O} \quad$ G. $\quad$ bulloides $+0.27-5^{*}(4.38-$ $\left.\left((4.38)^{2}-0.4 *\left(16.9-T^{*}\right)\right)^{0.5}\right)$

Local salinity anomaly $=\delta_{\mathrm{sw}}-\delta_{\mathrm{gw}}$.

\subsection{Evidence against sources of error in the SST interpretation}

The possibility of selective dissolution of radiolarian assemblages causing the MIS 10 SSST anomaly, by an artificial bias of the assemblage towards warmer indicator species, is excluded by both the good preservation of the radiolarian assemblage in this interval, and the presence of the same anomaly in the $\delta^{13} \mathrm{C}$ records. Moreover, the radiolarian assemblage observed in MIS 10 sediments is similar to interglacial radiolarian assemblages, with increased abundance of colonial radiolarians and Tetrapyle octacantha, and decreased abundance of Phorticium clevei. The latter two species are dissolution resistant, and the near absence during MIS 10 of $P$. clevei, a cold water indicator species abundant in sediments deposited during glacial intervals, also suggests that the observed warming cannot arise from selective dissolution of the radiolarian assemblages.

Radiolarian assemblages did not experience substantial evolution during the last $450 \mathrm{kyr}$, and their usage in transfer functions is therefore not dramatically affected by extinction or first appearance events of taxa. The only two such events were the First Occurrence (FO) of Buccinosphaera invaginata, dated at $0.18 \mathrm{Ma}$ [7], and the Last Occurrence (LO) of Stylatractus universus, dated at 0.42 Ma [8]. B. invaginata, a colonial, warm-water adapted species, is reported as very rare in modern sediments from the South Atlantic, reaching maximum abundances (however, up to only $1 \%$ ), in the South Atlantic Central Gyre [9]. This species is never present in our samples, and therefore does not influence our paleoSST reconstructions. We observed $S$. universus, in percentages lower than $1 \%$, in the bottom $3 \mathrm{~m}$ of our core, between 64 and 67 meters composite depth (mcd), corresponding to ages older than ca. 420 kyr. Its low abundance, and the fact that neither this taxon, nor the genus level taxon Stylatractus spp., were used in the transfer function excludes any bias of this extinction event on paleoSST.

The age assignment is also well constrained, as a marked decrease in $\delta^{18} \mathrm{O}$ Cibicidoides, leading into MIS 9, allows to clearly identify termination IV. Finally, the isotopic and paleoSSST records have been generated from the same sediment size fraction (ca. 50-200 $\mu \mathrm{m}$ ), thus avoiding the possibility of winnowing and different source areas for the two signals. 


\section{Results and discussion}

Our paleo-summer sea surface temperature (SSST) record at ODP Site 1089 (Fig. 3, Table 1) suggests that the magnitude of the glacial to interglacial rebound at last five terminations $\left(6-7{ }^{\circ} \mathrm{C}\right)$ compares well to both an LGM time slice SST mapping over the Atlantic Sector of the Southern Ocean [10], and the maximum LGM zonal mean SST reduction $\left(5{ }^{\circ} \mathrm{C}\right)$ predicted by the Goddard Institute for Space Studies (GISS) model [11] at $43^{\circ} \mathrm{S}$. The climatic evolution of ODP Site 1089 clearly displays glacial-interglacial alternations, with one notable exception: an anomaly at ca. $350 \mathrm{ka}$ (Figs. 3 and 4) when, in the midst of a glacial interval (Marine Isotope Stage, MIS 10), SSST values for this core, located in the subantarctic Atlantic Ocean, are close to interglacial SSST. The observed MIS 10 anomaly is present, although subdued and slightly diachronous, in the $\delta^{13} \mathrm{C}$, while much reduced in extent in the $\delta^{18} \mathrm{O}$, planktic and benthic foraminifera isotopic records from the same core (Fig. $3)$. Its more marked appearance in the planktic than in the benthic $\delta^{13} \mathrm{C}$ records demonstrates how it is a dominantly surface water signal, but apparently caused by processes that do not leave a strong imprint in the $\delta^{18} \mathrm{O}$ records. This can be related to the fact that the $\delta^{18} \mathrm{O}$ from planktic foraminifera, at least at this location, fails to properly record the MIS 10 anomaly, due to the co-occurrence of a SST and a salinity increase during MIS 10. We calculated that this advection of warmer, but also saltier, than expected water for this glacial interval has induced a calculated local salinity anomaly for MIS 10 of $3.2 \%$, a value only reached since during the peak Eemian intergla-

Fig. 3. Comparison between insolation and climatic proxies from ODP Site 1089. Surface (SST, local salinity anomaly, $\delta^{18} \mathrm{O}$ and $\delta^{13} \mathrm{C}$ of the planktic foraminifer $G$. bulloides $)$ and deep $\left(\delta^{18} \mathrm{O}\right.$ and $\delta^{13} \mathrm{C}$ of the benthic foraminifer Cibicidoides spp.) hydrography proxies for ODP Site 1089, isotopic data are from [4]. The summer solstice insolation $\left(\mathrm{W} \mathrm{m}^{-2}\right)$ for the last $450 \mathrm{ka}$ at $30^{\circ} \mathrm{S}$ [36] is also shown. Note the reduced amplitude of the insolation forcing during the 350-450-ka interval, and the re-establishment of a stronger forcing at ca. $350 \mathrm{ka}$. The local salinity anomaly (Table 1) was calculated following the method described in [6], and as explained in detail in the Materials and methods paragraph. Its maximum during MIS 10 (to values only reached during the Eemian climatic optimum) coincides with higher SST at ODP Site 1089, suggesting the input of warmer and saltier waters from the Indian Ocean.

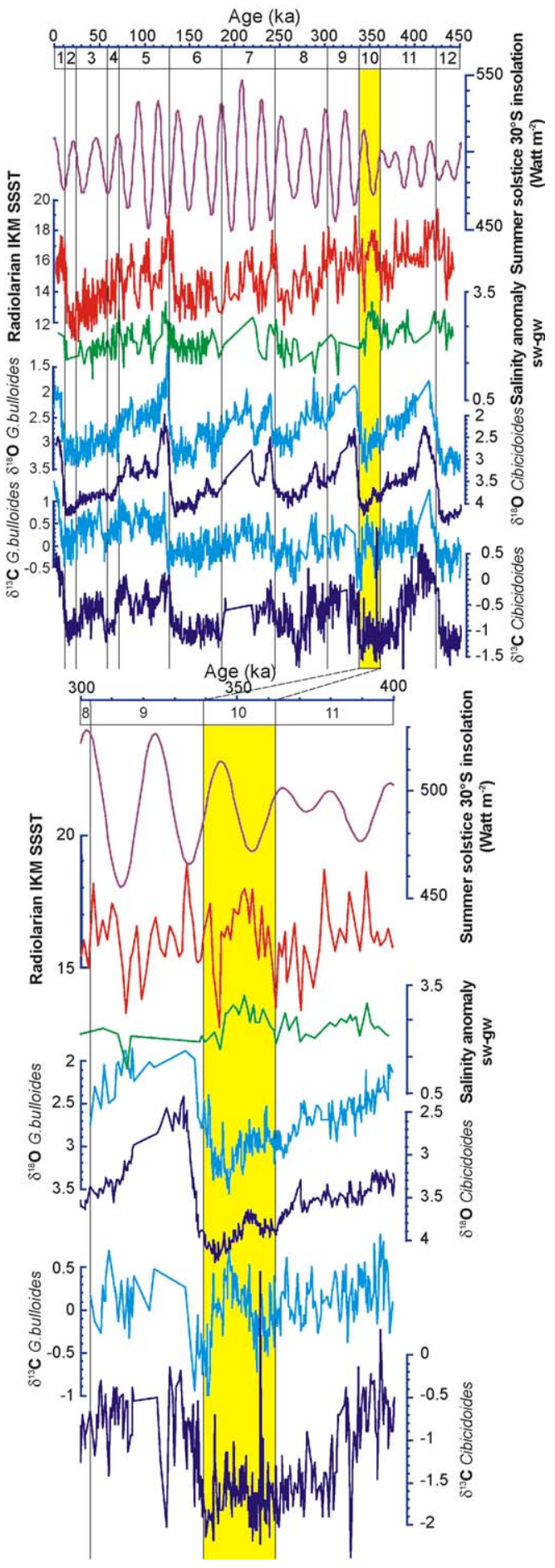


cial (Fig. 3). ${ }^{1}$ Therefore, while the observed ca. $5{ }^{\circ} \mathrm{C}$ SST increase from glacial background values during MIS 10 would contribute to a $1.1 \%$ decrease in the $\delta^{18} \mathrm{O}$ of planktic foraminifera, following the general $0.22 \% o=1{ }^{\circ} \mathrm{C}$ relationship [12], the $3.2 \%$ local salinity anomaly during the same period would increase the $\delta^{18} \mathrm{O}$ of planktic foraminifera by $1.6 \%$ o [13]. The two effects go in opposite directions, and almost cancel out in the study area, resulting, once ice-volume and other effects are included, in ca. $0.5 \%$ lighter $\delta^{18} \mathrm{O}$ planktic values compared to glacial baseline values, a rather "muted" isotopic signature, compared to the much higher SST change taking place at the same time. The Agulhas Retroflection area is, however, very special with respect to surface salinity anomalies, representing the main conduit of heat and salt from the Indian to the Atlantic Ocean, and being located very close to the STF, separating warmer and saltier subtropical waters from colder and fresher subantarctic waters. In other areas, characterized by less steep gradients and boundaries between very different water masses, and presumably lower local salinity contrasts between glacial and interglacial times, the SST signal would probably be the dominant signature in the planktic $\delta^{18} \mathrm{O}$ signal, pulling it towards lighter values, and therefore better recording the SST anomaly. For this reason, the previous argumentation about the muted $\delta^{18} \mathrm{O}$ signal in the Agulhas Retroflection area does not exclude the utilization of $\delta^{18} \mathrm{O}$ from planktic foraminifera as a tracer of the MIS 10 SST anomaly in other areas, as long as their surface water masses were not experiencing major salinity anomalies in addition to the global glacial increase.

While the opposed effects of seawater temperature and salinity changes dampen the $\delta^{18} \mathrm{O} G$. bulloides record, the $\delta^{13} \mathrm{C}$ signal, on the contrary, is very efficient at recording the MIS 10 SST anomaly. We therefore interpret the latter as having a strong surface productivity imprint. The strong link between Agulhas SST and productivity in our study area is a result of the flow characteristics of this western boundary current, and their consequences on the thermocline/nutricline depth. In fact, satellite-based measurements of ocean color and altimetry allow to

\footnotetext{
${ }^{1}$ See online version of this paper for a table containing salinity estimates.
}

recognize the frontal system formed by the Agulhas Return Current and the subtropical convergence zone as an area of elevated productivity, intense turbulence and eddy activity. ${ }^{2}$ Under present conditions, a crescent of high summer productivity (Fig. 2, left panel) is frequently observed between the Cape of Good Hope and the STF. This elevated productivity is related to the particularly high ocean dynamic topography variability displayed by the Agulhas Current $^{2}$, a trait it shares with other major western boundary currents (Brazil Current, Kuroshio Current, Gulf Stream). This is a consequence of the strong shedding of mesoscale eddies in the area, linked to the shoaling of this current against the Agulhas Bank. The latter topographic high also favours the formation of internal (baroclinic) tides [14], with an additional modulating effect by the current strength [15]. Internal tides are the dominant source of energy driving deep mixing [16], as the energy they release when breaking increases mixing between deep and surface waters, thus contributing to the heat transfer through the upper ocean [17], and most importantly affects the depth of the thermocline/nutricline. Primary productivity in our study area is therefore today indirectly related to SST, as a stronger Agulhas Current not only implies higher SST, but also reflects stronger eddy shedding, baroclinic tides, and high ocean dynamic topography variability. This results in a variable nutricline depth, which occasionally becomes shallow, thus giving easier access to nutrients in the surface layer, and generating high primary production.

The heavier $\delta^{13} \mathrm{C}$ values found during MIS 10 at ODP Site 1089 could then represent a period of intensified productivity, caused by a circulation rearrangement: an anomalous broadening and/or intensification of Agulhas spillover advected more/warmer waters than usual in the subantarctic Atlantic Ocean from the subtropical Indian Ocean, thus increasing oceanic mixing and productivity. An indication of increased productivity in this region during this time period comes from ODP Site 1090 [18], where $C_{\text {org }}$, opal and carbonate mean accumulation rates all display a maximum during MIS 10 , to values twice as high as ever reached since. Increased productivity during MIS 10 seems also to be confirmed by recent

\footnotetext{
${ }^{2}$ See online version of this paper for satellite images.
} 


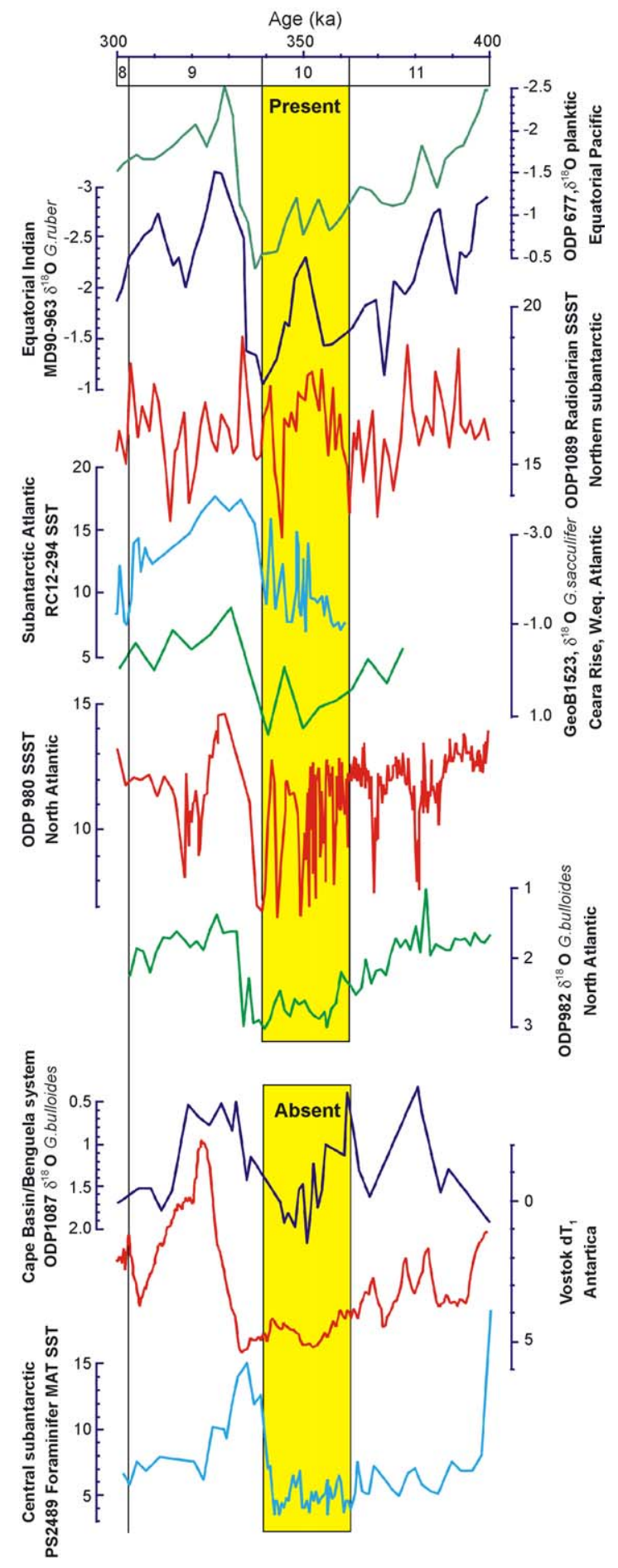

primary productivity data for ODP Site 1089 [19], which indicate high values (average of ca. $150 \mathrm{~g} \mathrm{C}$ $\mathrm{m}^{-2} \mathrm{y}^{-1}$ ) between 400 and $350 \mathrm{ka}$. The peak values reached during MIS $10\left(170 \mathrm{~g} \mathrm{C} \mathrm{m}^{-2} \mathrm{y}^{-1}\right.$ at $\left.350 \mathrm{ka}\right)$ are only matched once afterwards (at $300 \mathrm{ka}$ ), while primary productivity fluctuated around an average value of ca. $115 \mathrm{~g} \mathrm{C} \mathrm{m}^{-2} \mathrm{y}^{-1}$ since then.

The MIS 10 SST anomaly recognized at ODP Site 1089 (subantarctic Atlantic Ocean) is also present in other paleoclimatic proxies (Fig. 4) at ODP Site 677 (eastern equatorial Pacific Ocean), MD90-963 (equatorial Indian Ocean), RC12-294 (subantarctic Atlantic Ocean), GeoB1523 (Ceara Rise, western equatorial Atlantic), ODP Sites 980 and 982 (North Atlantic Ocean), as well as in other records not shown in Fig. 4: MD96-2085 (eastern subtropical South Atlantic) [20], GeoB1309 and GeoB1312 (Rio Grande Rise, eastern equatorial Atlantic) [21], M35027-1 (western subtropical North Atlantic) [22], KL11 (Red Sea) [23]. The MIS 10 anomaly is particularly distinct at ODP Site 1089, ODP Site 980, and core MD90-963, all situated at locations where oceanic and atmospheric overturning cells and fronts interact most strongly, and thus possibly provide amplifying feedback mechanisms. A high-resolution, $\mathrm{Mg} / \mathrm{Ca}$-derived SST record [24] from core MD97-2120, from the Chatham Rise, in the southwestern Pacific, also displays SST warm anomalies during the last three glacials, of a magnitude reaching up to half the glacial to interglacial SST change, and just preceding terminations. This site shares many similarities with ODP Site 1089 , as it is located in the subantarctic zone, just to the south of the

Fig. 4. Comparison to climatic records from other cores. Surface hydrography proxies (SST, $\delta^{18} \mathrm{O}$ per mil PDB of planktic foraminifera), and $\mathrm{d} T$ at the atmospheric inversion layer (Vostok) for the cores shown in Fig. 1. Cores have been separated in two broad groups, those displaying (Present) and those missing (Absent) the MIS 10 SSST anomaly, and are arranged along the THC surface branch, starting from the equatorial Pacific and ending with the North Atlantic Ocean. Ages are according to the original age models, and in ka, with the exception of core MD90-963 (age in kyr B.P.). Age model and data sources are as follows: ODP Site 677 [37], MD90-963 [38], Vostok [27], PS2489 [39], ODP Site 1087 [40], ODP Site 980 [41], RC12-294 [42], GeoB1523 [21], ODP Site 982 [43]. The MIS 10 anomaly is most clear at ODP Site 980 (Rockall Plateau, North Atlantic) and at core MD90-963 (equatorial Indian Ocean). It is however difficult to assess cause-effect relationships and exact chronological sequences of events between records, as the dating, to within a few ka, of climate events and terminations is problematic. 
Subtropical Front, in an area of strong ocean-atmosphere interaction, and lies close to a topographic high (the Chatham Rise) which induces strong eddy activity and baroclinic tides. Unfortunately, MD97-2120 does not, however, extend down to MIS 10.

All the above mentioned records are situated along the THC path (Figs. 1 and 4), both upstream (e.g. ODP Site 677 and MD90-963) and downstream (e.g. OPD Site 980) from the Agulhas region. This suggests the existence of a strong oceanic connection between the equatorial Indo-Pacific Ocean, the Cape Basin and the North Atlantic, acting as an efficient climatic signal transfer mechanism, although the determination of the phase relationship between these records is hindered by their age models being based on different methods.

This anomaly is not observed either in the Vostok ice core deuterium $(\delta \mathrm{D})$, or in oceanic records southwards of the central Subantarctic Zone. The absence of the MIS 10 SSST anomaly from these records further suggests its low latitude and oceanic nature. In fact, an atmospheric general circulation model study [25] indicates that the main source area for precipitation on Antarctica is at subtropical and midlatitudes for present-day conditions, while it shifts to the lower latitude end (i.e. subtropics) during glacial conditions. In particular, for the Vostok site, the main moisture source is located in the subtropical Indian Ocean. The deuterium excess record of the Vostok ice core is interpreted [26] as a tracer of temperature at these moisture sources. During MIS 10, it indicates an increase of $3.5^{\circ} \mathrm{C}$ at the moisture source (compared to a $5{ }^{\circ} \mathrm{C}$ temperature increase at the ensuing termination), whose magnitude is therefore more significative than the coeval $2.4{ }^{\circ} \mathrm{C}$ shift at the Vostok site (where the temperature change at the termination is of 11.4 ${ }^{\circ} \mathrm{C}$ ). This peak occurs just before termination IV, and is centered around $342 \mathrm{ka}$ [26], based on the GT4 chronology of Vostok [27]. The accuracy of this chronology is however $\pm 15 \mathrm{ka}$ for the oldest part of the record [27], making this peak potentially correlative to the one (centered around $350 \mathrm{ka}$ ) recognized in our core.

The warm SST anomaly in the Cape Basin during the glacial MIS 10 is therefore indirectly predicted by the Vostok deuterium excess record, which represents an independent proxy (derived from hydrogen and oxygen isotopes from the Vostok ice core), and forecasts the presence of warmer than expected temper- atures during MIS 10 in the subtropical Indian Ocean. As the latter is also the source area for the Agulhas Current, we believe that our SST record is capable of capturing the same signal, and thus, in turn, gives strong support to the interpretation of the Vostok deuterium excess record in terms of temperature at the moisture source.

The presence of the MIS 10 anomaly in the Vostok deuterium excess record (reflecting subtropical conditions), and its absence from the Vostok $\delta \mathrm{D}$ record (linked to local antarctic conditions), again confirm how this signal is generated at low latitudes, most likely by ocean-related processes.

The absence of the anomaly at PS2489 (central Subantarctic Zone) indicates how this location was not affected by either the Agulhas spillage, or STF oceanic processes, which instead play an important role at northern subantarctic latitudes, and the limit between these two provinces was probably just south of ODP Site 1089 (Fig. 2). We also do not expect the MIS 10 anomaly to be present in the Cape Region upwelling, as the mechanisms driving the Agulhas spillage (insolation in the intertropical Indo-Pacific Ocean) are spatially separated from those driving the upwelling system (trade winds intensity and direction around South Africa). There might also be a time separation between the two processes, as Agulhas spillage is stronger during austral summer ${ }^{3}$, while the maximum Cape Region upwelling intensity is reached during winter [28]. For these reasons, the MIS 10 SSST anomaly is absent from the $\delta^{18} \mathrm{O} G$. bulloides record of ODP Site 1087 (Fig. 4).

Core MD96-2080, from the western Agulhas Bank Slope (Fig. 2), revealed cold-water intrusions from the northern subantarctic during glacials for the last 450 kyr [29]. According to these authors, the leakage of cold water during glacials would have occurred from the northern subantarctic through the Subtropical Convergence, as part of Agulhas ring shedding, as the STF would have been closer to the Agulhas Bank during glacials, making this area prone to eddy shedding, and not to filaments, as it is instead the case today. The absence of the MIS 10 anomaly from core MD96-2080, apart from considerations on the complexity of local oceanography, may then be

\footnotetext{
3 See online version of this paper for a movie showing the annual SST evolution in this area.
} 
explained by its location on the opposite side of the Agulhas Current compared to ODP Site 1089. This results in cold rings being shed northwards toward the Agulhas Bank during glacials, while at the same time warm rings are shed southwards to the northern subantarctic. Moreover, as the connection between South Indian Ocean and South Atlantic Ocean was never entirely obstructed during the last $450 \mathrm{kyr}$, and actually maximum warm leakage from the Indian Ocean occurred at glacial terminations [29], it is also possible that the Agulhas Current had, during glacials, a more jet-like character (due to stronger gradients and general circulation, and narrower "Agulhas valve" during glacials), making its influence less felt on the leeward side of the Agulhas Bank, compared to the more offshore location of ODP Site 1089.

The SST and planktic $\delta^{13} \mathrm{C}$ signals from ODP Site 1089 indicate that surface hydrography at our subantarctic location was affected, during MIS 10, by an event not related to the normal glacial-interglacial forcing. The marked character of the MIS 10 anomaly at the location of ODP Site 1089 is a consequence of the proximity of this site to both the STF and the "Agulhas Gate". The STF represents a strong oceanographic boundary, with a steep SST gradient, and is strongly affected by bottom topography, which limits major frontal movements between two relatively stable positions, either to the south or to the north of the Agulhas Ridge. Eddy transport is also strong across this front, with cold-core eddies transported northwards, and warm-core eddies transported southwards. All these factors conjure to allow large, sudden SST shifts in the proximity of this front.

Moreover, the external insolation forcing is particularly direct in the tropical Indo-Pacific where, on seasonal to interannual timescales (e.g. El Niño, Indian Dipole Mode), the atmosphere is very sensitive to oceanic temperature and salinity anomalies [30]. Modulations on longer timescales (decennial to millennial) of these basin-scale dipoles, demonstrated to exist at decadal scale [31], have the potential to segregate moisture in different parts of an ocean, thus affecting surface water density and THC intensity. These events are then globally transmitted from the Indo-Pacific global heat pool, with the "Agulhas Gate" representing the main conduit of heat and water fluxes from the Indian to the Atlantic Ocean.
The cause of the prolonged discharge of warm water around South Africa during MIS 10 was probably the Agulhas Current reaction to the switch to enhanced insolation amplitude variability taking place (Fig. 3) at $30^{\circ} \mathrm{S}$, in the Agulhas Current source region, off Madagascar. The expansion of the Agulhas Current during periods of high, and retreat during periods of low, insolation at its source areas would represent a long term equivalent of the short term, seasonal, coincidence between late summer insolation increase at the Cape Basin latitudes and an Agulhas spillage peak, with the winter being instead characterized by a reduction of the current. ${ }^{3}$ Today, most of the incoming energy from the Sun is stored at intertropical latitudes, and the thermic contrast arising from the unequal distribution of heat between low and high latitudes is one of the main mechanisms driving the oceanic and atmospheric currents which redistribute the excess heat from the tropics to higher latitudes. In a similar fashion, lower insolation variability would have accumulated heat mostly at intertropical latitudes in the Indian and Pacific Ocean before $350 \mathrm{ka}$. On the contrary, stronger insolation variability starting at $350 \mathrm{ka}$ (Fig. 3) lead to expansion of the warm water sphere in connection to insolation peaks, enhanced temperature gradients, more vigorous circulation and increased Agulhas Current activity, which allowed intensified Agulhas spillover into the Atlantic, thus flushing the South Atlantic Ocean with the heat previously accumulated in the Indo/Pacific tropics.

\section{Conclusions}

A radiolarian-based transfer function allowed the reconstruction of a 450,000 years long record of SSST changes at ODP Site 1089, located close to the subtropical front, in the Atlantic Sector of the Southern Ocean. The general aspect of this record, also confirmed by $\delta^{18} \mathrm{O}$ and $\delta^{13} \mathrm{C}$ isotopic measurements on planktic and benthic foraminifera [4], consists of the well-known alternation, at an orbital time scale, between interglacial and glacial time intervals. A warm water anomaly stands out from this pattern, as SSST during MIS 10 (a full glacial time interval) reaches values close to those prevailing during interglacial intervals. This anomaly might be connected to the transition, taking place at ca. $350 \mathrm{ka}$, to higher 
amplitude insolation variability in the Agulhas Current source area, causing a flushing of the South Atlantic with warm waters previously heated in the intertropical Indian and Pacific Oceans.

If our explanation for the MIS 10 anomaly in terms of an insolation variability switch is correct, we might expect that a future Agulhas SSST anomaly event will further delay the onset of next glacial age, as the insolation forcing conditions for the Holocene (the current interglacial), are very similar to those present during MIS 11 (the interglacial preceding MIS 10), as both periods are characterized by a low insolation variability for the Agulhas Current source area (Fig. 3). Natural climatic variability will therefore force the Earth system in the same direction as the anthropogenic global warming trend, and will thus lead to even warmer than expected global temperatures in the near future.

\section{Acknowledgements}

We thank Chris Charles for sharing his isotope data from ODP Site 1089, and Ute Bock for sample preparation. Useful comments and fruitful discussions have been provided by Andreas Mackensen and Ulrike Wacker, as well as by two anonymous reviewers. This research was funded by the Deutsche Forschungsgemeinschaft (DFG) through Sonderforschungsbereich (SFB) 261, and as part of the DFGResearch Center "Ocean Margins" of the University of Bremen, No. RCOMO138. [BARD]

\section{References}

[1] S. Manabe, R.J. Stouffer, Coupled ocean-atmosphere model response to freshwater input: comparison to Younger Dryas event, Paleoceanography 12 (1997) 321-336.

[2] A.L.J. Gordon, Interocean exchange of thermocline water, Journal of Geophysical Research 91 (1986) 5037-5046.

[3] G. Cortese, A. Abelmann, Radiolarian-based paleotemperatures during the last 160 kyrs at ODP Site 1089 (Southern Ocean, Atlantic Sector), Palaeogeography, Palaeoclimatology, Palaeoecology 182 (2002) 259-286.

[4] D.A. Hodell, C.D. Charles, J.H. Curtis, P.G. Mortyn, U.S. Ninnemann, K.A. Venz, Data report: oxygen isotope stratigraphy of ODP Leg 177 Sites 1088, 1089, 1090, 1093, and 1094, in: R. Gersonde, D.A. Hodell, P. Blum (Eds.), Proc. ODP, Sci. Results, 2003, http://www.odp.tamu.edu/publications/ 177_SR/chap_09/.
[5] M.L. Bender, Orbital tuning chronology for the Vostok climate record supported by trapped gas composition, Earth and Planetary Science Letters 204 (2002) 275-289.

[6] L.D. Labeyrie, M. Labracherie, N. Gorfti, J.J. Pichon, M. Vautravers, M. Arnold, J.C. Duplessy, M. Paterne, W. Michel, J. Duprat, M. Caralp, J.L. Turon, Hydrographic changes of the Southern Ocean (southeast Indian sector) over the last $230 \mathrm{kyr}$, Paleoceanography 11 (1996) 57-76.

[7] D.A. Johnson, D.A. Schneider, C.A. Nigrini, J.-P. Caulet, D.V. Kent, Pliocene-Pleistocene radiolarian events and magnetostratigraphic calibrations for the tropical Indian Ocean, Marine Micropaleontology 14 (1989) 33-66.

[8] N.J. Shackleton, S. Crowhurst, T. Hagelberg, N.G. Pisias, D.A. Schneider, A new late Neogene time scale: application to Leg 138 sites, in: N.G. Pisias, L.A. Mayer, T.R. Janecek, A. Palmer-Julson, T.H. vanAndel (Eds.), Proc. ODP, Sci. Results, Ocean Drilling Program, College Station, TX, 1995, pp. $73-101$.

[9] D. Boltovskoy, Classification and distribution of South Atlantic Recent Polycystine Radiolaria, Paleontologica Electronica 1 (1998).

[10] R. Gersonde, A. Abelmann, U. Brathauer, S. Becquey, C. Bianchi, G. Cortese, H. Grobe, G. Kuhn, H.-S. Niebler, M. Segl, R. Sieger, U. Zielinski, D.K. Fütterer, Last glacial seasurface temperatures and sea-ice extent in the Southern Ocean (Atlantic-Indian sector) - a multiproxy approach, Paleoceanography 18 (2003) 1061 (doi:1029/2002PA000809).

[11] R.S. Webb, D.H. Rind, S.J. Lehman, R.J. Healy, D. Sigman, Influence of ocean heat transport on the climate of the last glacial maximum, Nature 385 (1997) 695-699.

[12] S. Epstein, R. Buchsbaum, H.A. Lowenstam, H.C. Urey, Revised carbonate-water isotopic temperature scale, Geological Society of America Bulletin 64 (1953) 1315-1326.

[13] H. Craig, L.I. Gordon, Deuterium and Oxygen 18 variations in the ocean and the marine atmosphere, in: E. Tongiorgi (Ed.), Stable isotopes in oceanographic studies and paleotemperatures, C.N.R., Pisa, 1965, pp. 9-130.

[14] P. Penven, J.R.E. Lutjeharms, P. Marchesiello, C. Roy, S.J. Weeks, Generation of cyclonic eddies by the Agulhas current in the lee of the Agulhas bank, Geophysical Research Letters 28 (2001) 1055-1058.

[15] R. Robertson, Internal tides and baroclinicity in the southern Weddell Sea 1. Model description, Journal of Geophysical Research 106 (2001) 27001-27016.

[16] W. Munk, C. Wunsch, Abyssal recipes II: energetics of tidal and wind mixing, Deep Sea Research 45 (1998) 1977-2010.

[17] R. Robertson, Mixing and heat flux mechanisms in the upper ocean in the Weddell Sea, PhD thesis, Oregon State University, Corvallis, 1999, 173 pp.

[18] B. Diekmann, G. Kuhn, Sedimentary record of the mid-Pleistocene climate transition in the southeastern South Atlantic (ODP Site 1090), Palaeogeography, Palaeoclimatology, Palaeoecology 182 (2002) 241-258.

[19] G. Kuhn, R. Gersonde, G. Cortese, P. Weller, A paleoproductivity transect across the Antarctic Circumpolar Current in the Late Quaternary South Atlantic, EGU 1st Plenary Meet., Nice, France, 25-30 April, 2004. 
[20] M.-T. Chen, Y.-P. Chang, C.-C. Chang, L.-W. Wang, C.-H. Wang, E.-F. Yu, Late Quaternary sea-surface temperature variations in the southeast Atlantic: a planktic foraminifer faunal record of the past $600000 \mathrm{yr}$ (IMAGES II MD962085), Marine Geology 180 (2002) 163-181.

[21] W. Hale, U. Pflaumann, Sea-surface temperature estimations using a modern analog technique with foraminiferal assemblages from Western Atlantic Quaternary sediments, in: G. Fischer, G. Wefer (Eds.), Use of Proxies in Paleoceanography: Examples from the South Atlantic, Springer, Berlin, 1999, pp. 69-90.

[22] A. Stüber, Spätpleistozäne Variabilität der Zwischenwasserzirkulation im Subtropischen Westatlantik auf Glazial-Interglazialen und Suborbitalen Zeitskalen: Rekonstruktion anhand Stabiler Kohlenstoffisotope und Spurenmetallverhaltnisse in Kalkigen Benthos-foraminiferen, $\mathrm{PhD}$ thesis, University of Kiel, Kiel, 1999, 118 pp.

[23] C. Hemleben, D. Meischner, R. Zahn, A. Almogi-Labin, H. Erlenkeuser, B. Hiller, Three hundred eighty thousand year long stable isotope and faunal records from the Red Sea: influence of global sea level change on hydrography, Paleoceanography 11 (1996) 147-156.

[24] K. Pahnke, R. Zahn, H. Elderfield, M. Schulz, 340,000-year centennial-scale marine record of Southern Hemisphere climatic oscillation, Science 301 (2003) 948-952.

[25] G. Delaygue, V. Masson, J. Jouzel, R.D. Koster, R. Healey, The origin of Antarctic precipitation: a modelling approach, Tellus 52B (2000) 19-36.

[26] F. Vimeux, K.M. Cuffey, J. Jouzel, New insights into Southern Hemisphere temperature changes from Vostok ice cores using deuterium excess correction, Earth and Planetary Science Letters 203 (2002) 829-843.

[27] J.R. Petit, J. Jouzel, D. Raynaud, N.I. Barkov, J.M. Barnola, I. Basile, M. Bender, J. Chappellaz, M. Davis, G. Delaygue, M. Delmotte, V.M. Kotlyakov, M. Legrand, V.Y. Lipenkov, C. Lorius, L. Pépin, C. Ritz, E. Saltzman, M. Stievenard, Climate and atmospheric history of the past 420,000 years from the Vostok ice core, Antarctica, Nature 399 (1999) 429-436.

[28] W.W. Hay, J.C. Brock, Temporal variation in intensity of upwelling off southwest Africa, in: C.P. Summerhayes, W.L. Emeis, K.C. Emeis (Eds.), Upwelling Systems: Evolution Since the Early Miocene, Geol. Soc. London Spec. Publ. 64, (1992) 463-497.

[29] A.J. Rau, J. Rogers, J.R.E. Lutjeharms, J. Giraudeau, J.A. Lee-Thorp, M.-T. Chen, C. Waelbroeck, A 450-kyr record of hydrological conditions on the western Agulhas Bank Slope, South of Africa, Marine Geology 180 (2002) 183-201.

[30] R.T. Pierrehumbert, Climate change and the tropical Pacific: the sleeping dragon wakes, Proceedings of the National Academy of Science 97 (2000) 1355-1358.

[31] A. Timmermann, Decadal ENSO amplitude modulations: a nonlinear paradigm, Global and Planetary Change 37 (2003) $135-156$.

[32] A.C. Mix, D.C. Lund, N.G. Pisias, P. Bodén, L. Bornmalm, M. Lyle, J. Pike, Rapid climate oscillations in the Northeast Pacific during the last deglaciation reflect Northern and Southern Hemisphere sources, in: P.U. Clark, R.S. Webb, L.D. Keigwin (Eds.), Mechanisms of global climate change, American Geophysical Union, Washington, D.C, 1999, pp. 127-148.

[33] H. Schulz, U. von Rad, H. Erlenkeuser, Correlation between Arabian Sea and Greenland climate oscillations of the past 110,000 years, Nature 393 (1998) 54-57.

[34] C. Provost, F. Vivier, V. Garçon, I. Dadou, E. Machu, South Atlantic Ocean and Southern Ocean, Aviso Altimetry Newsletter 8 (2003) (http://www-aviso.cnes.fr).

[35] Naval Research Laboratory, Real-Time Global Ocean Analysis and Modeling: $1 / 16^{\circ}$ Global Naval Research Lab Layered Ocean Model Nowcast/Forecast of surface temperature (SST), Naval Oceanographic Office, Stennis Space Center, MS, USA (2003).

[36] J. Laskar, The chaotic motion of the Solar System: a numerical estimate of the size of the chaotic zones, Icarus 88 (1990) $266-291$.

[37] N.J. Shackleton, A. Berger, W.R. Peltier, An alternative astronomical calibration of the Lower Pleistocene timescale based on ODP Site 677, Earth Sciences 81 (1990) 251-261.

[38] F.C. Bassinot, L.D. Labeyrie, E. Vincent, X. Quidelleur, N.J. Schackleton, Y. Lancelot, The astronomical theory of climate and the age of the Brunhes-Matuyama magnetic reversal, Earth and Planetary Science Letters 126 (1994) 91-108.

[39] S. Becquey, R. Gersonde, A 0.55-Ma paleotemperature record from the Subantarctic zone: Implications for Antarctic circumpolar current development, Paleoceanography 18 (2003) 1014 (doi:10.1029/2000PA000576).

[40] C. Pierre, J.F. Saliege, M.J. Urrutiaguer, J. Giraudeau, Stable isotope record of the last 500 k.y. at Site 1087 (Southern Cape Basin), in: G. Wefer, W.H. Berger, C. Richter (Eds.), Proc. ODP, Sci. Results, 2001, pp. 1-22, Available from World Wide Web: http://www-odp.tamu.edu/publications/175-SR/ VOLUME/CHAPTERS/SR175-12.PDF [Online].

[41] J.F. McManus, D.W. Oppo, J.L. Cullen, A 0.5-million-year record of millennial-scale climate variability in the North Atlantic, Science 283 (1999) 971-975.

[42] T. Wolff, B. Grieger, W. Hale, A. Dürkoop, S. Mulitza, J. Pätzold, G. Wefer, On the reconstruction of paleosalinities, in: G. Fisher, G. Wefer (Eds.), Use of Proxies in Paleoceanography: Examples from the South Atlantic, Springer-Verlag, Berlin, 1999, pp. 207-228.

[43] K.A. Venz, D. Hodell, C. Stanton, D.A. Warnke, A 1.0 Myr record of Glacial North Atlantic Intermediate Water variability from ODP site 982 in the northeast Atlantic, Paleoceanography 14 (1999) $42-52$. 